\title{
The Expansion of Chinese Business in Myanmar and Sino-Myanmar Relations (1988-1990)
}

\author{
Olga Volosyuk, Wai Yan Phyo Naing \\ National Research University - Higher School of Economics \\ 20, Myasnitskaya Ulitsa, Moscow, Russia, 101000
}

This article deals with the evolution of Sino-Myanmar relations in the late 1980s as a result of the Chinese economic expansion. The "8888 Uprising" of August 1988 was suppressed be the military who retook power in the country. Condemning the repressions of the military government, Western countries and Japan sharply reduced aid to Burma. India closed borders and set up refugee camps along its border with Burma. This situation led to the almost complete isolation of Burma in the international community. China appeared as the only strategic ally of the country in the region. According to the official statistics, Chinese businesses were significantly expanded in Myanmar in 1988-1990. However, despite the remarkable improvement in trade dialogue, problems such as migrants and unbalanced trade emerged, creating fissures in Sino-Myanmar ties. The article examines various cases which caused a negative attitude of the people of Myanmar towards the Chinese and even led to the emergence of a term such as Sinophobia.

Key Words: Burma Socialist Programme Party; Myanmar, China; US; USSR; U Ne Win; border trade; SLORC; Chinese Businesses; Yunnan; Bilateral Trade

\section{Introduction}

In 1988, Myanmar fell under to the Military government control after several months of reform-attempt movements from an authoritarian state to multi party state system. As a result of the bloody public rally suppression and failed power transition to the opposition party in 1990, the military government received harsh sanctions from the US and Europe. Since Myanmar became isolated from the international community, the country turned into a pawn of China in the region. Sino-Myanmar relations had never been better than in 1988-1989. As seen by the results of Chinese economic expansion in Myanmar of that period, it can be said that the two countries future relations had its origins for Myanmar.

(C) Volosyuk Olga, Wai Yan Phyo Naing, 2019.

(c) (i) This work is licensed under a Creative Commons Attribution 4.0 International License https://creativecommons.org/licenses/by/4.0/ 
There are some clear-out problems in two countries relations. For the solution, we should not neglect the sources from the past. This neglect led to suppressed knowledge on the Sino-Myanmar relations. Therefore, this article differs from the Western scholars' works by comparing the exciting relationship with contemporary Sino-Myanmar relations. The best example could be Modern China-Myanmar Relations: Dilemmas of Mutual Dependence, by David I. Steinburg and Hong Wei Fun. They concentrated on every step of Sino-Myanmar relations, and their investigation gave the Western scholars a bright insight into the two countries relations. Although, they studied the US interests and policies on SinoMyanmar relations, they did not state that Myanmar became the close ally of China as an outcome of the mistakes of US sanctions in the late 1988. Maung Aung Myoe, in his book In the name of Pauk-Phaw: Myanmar's China Policy Since 1948 examined the milestones of Sino-Myanmar relations since 1948. He gave the outlines for the expansion of Chinese business in Myanmar in late 1980s, but he paid attention only to the government-to-government relations within the conceptual framework of "Pauk-Phaw".

The future ties between the two countries obtained its real and strong origins in the Chinese economic expansions in the late 1980s. This is the reason why this period is considered to be crucial one from the China and Myanmar perspectives. This article is based on different primary sources, among which are: government documents, papers of international organizations, statistics, interviews and other.

\section{The Position of Burma in the late 1980s}

In 1987, the Burmese Socialist Programme Party (BSPP or Lanzin Party) failed in management of all domestic policies as a result; the role of Burma (the previous name of Myanmar until 1989) status in the international community was placed in the lowest level. On the other hand, there was tension between communist and democratic ideology in the Southeast Asian region. Myanmar leaders always adjusted their place in international affairs especially in the relations with China, because Myanmar received military assistants and anti-narcotics funding from the USA. For the USSR, Burma was a playground for ideological competition with the Western World. For this point, Prof. Ludmila Lutz-Auras mentioned that "during the period of the Cold War, Russia's interest in Myanmar was among other things driven by an ideological struggle against Western, and especially American, capitalism". [1, P. 191].

$\mathrm{U}$ Ne Win, the president of the BSPP, initiated the economic policy based on the Burmese Way to Socialism program. Unfortunately, this policy plunged the country in a stagnant state. According to the UN's announcement, Burma was classified as "least-developed nation" in December 1987 [2, P. 169]. Actually, the government requested the UN to announce them as an LDP. Later, the Myanmar leaders asked to get aid and erase the US\$ 3.4 billion debt owed to the international community. According to Andrew M. Deutz, "this program proved eco- 
nomically unfeasible and was eventually loosened in the 1970s and 1980s" [2, P. 169]. The people of Myanmar who remembered their country as a golden land for its rich fertile soil and minerals country, were hugely disappointed with the then-government for this LDP announcement [3].

According to the Burmese Way to Socialism program, Burma had an isolated economic system and, therefore, there was a lack of export possibilities and also import products to other countries. That halted the official trade between Burma and its partners, which in turn, worsen the nation's impoverished situation. The BSPP government had to look for economic aid that could uplift the situation, as it happened when the US offered its assistance in 1986. From the statics of the US State Department, Washington provided US\$ 4-5 million annually as antinarcotics funding in the 1980 s, including aircraft, herbicide, and pilot training to Burma [2, P. 169]. From other perspectives, US aid was intended to be used in military operations against the Burmese Communist Party [9], and to suppress all opium fields planted in near BCP's critical bases alongside the Sino-Myanmar border. Meanwhile, the official trade between Burma and the US amounted to US\$ 10-12 million [2, P. 169] in the late 1980s.

As a Socialist country, Burma maintained relations with USSR causing concern in Beijing with the Soviet influence and ideological support of the Burmese domestic problems. Lutz-Auras wrote about BSPP's policy towards the Soviet Union that "Ne Win's leadership preferred not to antagonize its big neighbor [China], and reduced contact with its former ally so that no high-level Soviet officials visited Burma for a long time" [1, P. 173]. On the other hand, BSPP had good relations with the US, receiving aid from Washington.

Therefore, there were no critical events in the Soviet Union-Burma relationship in the late 1980s. The BSPP was supported by the Soviet when they seized the state power using the military in 1962. Since the BSPP came in power, they had tried reconciliation with Burmese Communist Party (BCP), but they never reached a cease-fire agreement. The Chinese-Soviet conflict alternatively affected the then-situation in 1970s. Beijing influenced the Burmese Communist Party as an ideological supporter and a main patron [4]. However, as a distinct sign of the special Soviet Union-Myanmar relationship, the Soviet Union's embassy enjoyed the biggest diplomatic compound in the Yangon (Rangoon) [5].

In the first period of the 1980s, the trade value between China and Burma did not influence the two countries relations. In 1988, it changed Burma future in all sectors and also Sino-Myanmar relationships. On 8.8.1988, a bloody Nationwide democracy movement shattered the BSPP government in Burma. On 18th of September 1988, the Military Generals seized the state power by founding "State Law and Order Restoration Council (SLORC)" [6, P. 194]. The US and Europe stood firmly against the SLORC and some countries even imposed harsh sanctions. Therefore, the SLORC looked back for their survival to its neighbors, mainly China and Thailand. Since Thailand was close to the US and supported many opposition groups of Tatmadaw (Military in Myanmar language) government, China became the first and the sole priority for the Generals of SLORC. Kudo 
Toshihiro mentioned that "under mounting international pressures on the military regime, Yangon had no choice but to approach Beijing for their survival" [7, P. 4].

\section{Burma Looks to China}

Since BSPP completely understood that they needed a transformation for the country's economic policy. U Ne Win, a paramount leader of BSPP, tried to implement reforms borrowed from the international community [9]. On the other hand, China promoted relationships with Myanmar in every sector. Beijing disconnected with BCP evidently and tended their policy straight towards the BSPP under Deng Xiaoping's management [4]. If we examine the chronology of SinoMyanmar delegations, we can see the development of the two countries bilateral relations since the start of the 1980s [8]. Even at the highest period of the democracy movement, a Chinese delegation led by the Vice Governor of Yunnan Province arrived at Yangon on July 27 and left on August 7, 1988 [8]. It was nearly a month before the military generals founded the SLORC as a new government. The day after the vice governor left, 8.8.1988, has become the day of nation-wide democracy revolution in Myanmar history.

We can assume that the BSPP already decided to open its border trade with Yunnan and initiated the intellectual talk with the Beijing on Myanmar economic reform, similar to that of China's "Open Up Policy". Local scholars indicated that BSPP leader did not intend to depend on China in everything [9]. If we look back to the first periods of coming to the power in 1988, the SLORC announced the market-based economy and opened foreign direct investments from the international. However, community the US, being the world leading economy, instead of supporting to the Myanmar economy, put sanctions and applied political pressure on SLORC. Europe also followed the US. The US even sent its aircraft carrier and four other warships to the Myanmar Sea [10, P. 107] under the reason of defense against the Chinese intervention in the democracy revolution. Not many western scholars described this critical condition in their research. According to Tin Maung Maung Than, there was no evidence that Beijing involved in supporting the $\mathrm{BCP}$, which was suspected to be an underground operator for all democratic movements at that time [6, P.194].

On the other hand, Beijing announced its policy that "China has consistently adhered to a policy of non-interference in the internal affairs of other countries, and Myanmar is also no exception. Myanmar is a neighboring country of China. We hope that situation there can be stabilized. There exist trade relations between China and Myanmar, which have not been suspended" said the Premier Li Peng on November 13, 1988 [10, P.107]. On 22nd of November 1988, SLORC opened its border trade office in Ruili, Yunnan, China and Muse, Shan State on Myanmar's side [12]. It was followed by the agreement between the Yunnan Provincial Import and Export Corporation and the Myanmar Export-Import Corporation in BSPP era. [13, P. 9].

When the SLORC introduced the new The Union of Myanmar Foreign Investment Law on 30 November 1988 [13, P. 233], the first investors who took this 
opportunity was China, especially traders from the Yunnan Province. The Military government of Myanmar opened border trade offices in several areas such as Lashio, Muse, Namhkam, and Kunglong [14, P. 213]. All of these places were located on the Sino-Myanmar border, and acted as important trade cities for the Myanmar-China relations since ancient times. Therefore, Myanmar opened the unique consumer markets for China, while China started imports Myanmar exports. According to David I. Steinburg and Hongwei Fun, "when Yangon opened its door and legalized border trade with China in 1988-1989, and because of the demonetization of much of Myanmar's currency in September 1987, China's commodities poured into the emerging consumer goods markets in Myanmar through legal and illegal channels" [15, P. 210].

Meanwhile, China provided the only channel for the SLORC leaders and their export to the rest of the world since neighboring Thailand and India supported the anti-military government and opposition armed groups on their borders. Similar to Myanmar, there were student movements in China in 1989, as an outcome of the contradiction of ideological conflicts between socialism and capitalism [16, P. 159]. To the international, it was known as the Tiananmen democracy revolution. The suppression of this movement stained Beijing's image on the global stage. As a result, the US and the Western World imposed sanctions on China, prompting China to look for new ways to remedy its trade concerns in the region.

Having an assess to the Indian Ocean, Myanmar became the ideal strategic gateway for Beijing's politics and goods trade. As an outcome, Sino-Myanmar relations reached a strategic height in all sectors. Steinberg and Hongwei Fun argued that "Chinese requirements at national and local levels for strategic and economic access to Myanmar and its resources to help fuel China's growth, and by internal Burmese needs for both economic support and a strategic partner against what the Burmese junta perceived as external threats, especially from the United States and through its ally, Thailand" [15, P. 156].

\section{Chinese Business Expansion in Myanmar}

In 1984, Myanmar President U San Yu paid a transit visit to Yunnan Province on his way to Beijing [10, P. 153]. He invited Yunnan authorities to visit Yangon. However, the bilateral trade between the two countries did not reach the development stage legally because of the socialist economic policy of BSPP. On the other hand, illegal border trade touched the highest volume according to the BSPP's survey in July 1988. Actually, BSPP started to implement a new economic policy in the mid-1980s [9]. Dr. Maung Maung, the six-day president during the prodemocracy revolution, asked his fellow citizens to wait patiently for the reform.

Already influenced by the opposition under-ground ideologies fed up by the BSPP's failed policies for over two decades, the Myanmar people did not accept his request and fought until the BSPP stepped down from absolute power [9]. With the lesson learned, the new military government, the SLORC, followed the BSPP 
reform plan in domestic policies since they took office. The SLORC opened it's first border trade offices in the Sino-Myanmar border region and began trading on 1st October 1988 [10, P. 155]. Since the SLORC started bilateral trade with China, especially with the Yunnan province, they legalized all illegal markets in the region. Aa a result, statistic of bilateral economic cooperation between the two countries steadily improved. According to the SLORC Trade Minister Colonel Abel, the Tatmadaw government expected to reach the total of US\$ 300 million in trade in the fiscal year of 1988-89 [8]. Many Chinese delegations and businesspeople started to appear as guests in Myanmar's governmental offices.

According to Beijing's statistics, in 1988, Myanmar's trade with China reached a total of US\$ 270.71 million [10, P. 152]. However, the total value of China's imports from and exports to Myanmar was US\$ 255.62 million [15, P. 209] If it is to be elaborated, there were some discrepancies between these two total values, although they came from the same source. For instance, Myanmar's export to China was US\$114.79 million, but according to another statistic, China’s import from Myanmar was US\$137.10 million for the same year, 1998. Therefore, Maung Aung Myoe mentioned that "it is generally agreed among Myanmar scholars that the Myanmar trade statistics are notoriously unreliable. The figures are, indeed, completely distorted. Chinese data is by no means accurate concerning Sino-Myanmar trade. It is nevertheless more reliable than that of Myanmar" [10, P. 153].

However, all discrepancies prove that the Chinese Business deals with Myanmar indeed developed rapidly through 1988-1991. Two countries total trade value was US\$327.62 million in 1990 [10, P. 152]. If we fixed Sino-Myanmar bilateral trade value in 1988 at US\$270.71 million, we could see a growth of US $\$ 56.91$ million in 1990. Base on this statistic, China received a trade surplus of US\$ 119.46 million from bilateral trade with Myanmar [15, P. 209]. According to the International Monetary Fund's estimates, China was not in the top level of Myanmar's major export partner but took first place among Myanmar's significant importers [17, P. 90].

China got an essential place in Myanmar's trading, but it was not balanced in all statistics. Myanmar bought much more goods from China than they exported to the Chinese market. Despite this fact, Sino-Myanmar bilateral trade was growing steadily and reached a total value of US\$392.09 million in 1991. Within one fiscal year, the economic cooperation between the two countries reached up to US\$64.47 million. However, from 1988 to 1990 , there was only US\$56.91 million in growth in Yangon-Beijing trade.

\section{Economic Relations towards Strategic Partnership}

The partnerships between Myanmar and China became a significant role after the SLORC's Vice-Chairman Lieutenant General Than Shwe, also Commander-in-Chief (Army), visited China in October 1989 [15, P. 302]. It was the first 
high level Myanmar military delegation to Beijing since 1978 [10, P. 144]. Myanmar Commander-in-Chief (Army) met with not only Chinese political leaders but also generals from PLA. Chinese Premier Li Peng stated that "PRC Pays serious consideration to friendships between the two nations and cooperation between the two-armed forces" [10, P. 145].

Both Western and Myanmar scholars agreed that Myanmar became a significant buyer for Chinese military hardware. No doubt, these opportunities arose from the US and Western sanctions. It contributed a major re-arming for Myanmar military omit from the Western arms embargo [11, P. 197]. As an outcome of SLORC's Vice-Chairman trip, in December 1989, Major General Tin Oo, Second Secretary of SLORC and Chief-of-Staff (Army), visited to Beijing and met with top PLA Generals. The Second Secretary signed the purchase agreement for military hardware amounting to US $\$ 1.2$ billion [10, P. 146] but it could not appear in the Myanmar government statistics because of the political sensitivity of this deal.

The SLORC leaders also received a number of promises from Beijing regarding the two countries economic and technical relations. Toshihiro Kudo mentioned that, Myanmar exported several products to China especially raw materials from natural resources. Non-metallic mineral manufactures accounted for 20.8\%, vegetables, and fruits in 14.6\% of total trade in 1988-1991. In exchange Beijing sold electrical items, textiles, and general industrial machinery and pieces of equipment to Myanmar [7, P. 22]. Also, many Chinese enterprises and companies poured their investments to the newly opened markets of Myanmar. Mainly, the garment industry rapidly expanded in the Myanmar's new industrial zones in Yangon. On August 20th, 1991, the Chairman of the SLORC, Senior General Saw Maung visited China and held discussions with President Yang Shangkun, General Secretary of Chinese Communist Party Jiang Zemin and Premier Li Peng in Beijing [12].

In his state visit, General Saw Maung expressed that "During this period, our two countries have enjoyed better understanding and greater cooperation with sympathy towards each other" [12] The Tatmadaw government got the RMB50 million loan from Beijing. As well as political guarantee, Chinese Premier promised that Beijing would never interfer in Myanmar's internal affairs [10, P. 111]. This stage of strategic partnership remedied problems in Sino-Myanmar relationships from 1988 to 1991. However, there were challenges such as massive migrant flows, and illegal merchandise increasing in those years. According to Tin Maung Maung Than, the Chinese migrants increased their presence by 56\% to 164\% from 1988 to 1993 in border areas with Yunnan Province [6, P. 206].

\section{Conclusion}

According to the Myanmar government statistics, out of 0.8 million SinoBurman living in Myanmar, 73,232 are Chinese citizen [15, P. 143]. In Myanmar's new economic policy, Chinese people in business were mentioned as cru- 
cial investors by every indicator. From some local researchers' works, most of leading Burmese-Chinese businesses in Myanmar are founded in the 1990s with the connections from the Mainland. In fact, Migration happens alongside with the Chinese investments to the major cities of Myanmar. As a well-established business base for Yunnan-Chinese, Mandalay saw a distinct increase in Yunnanese migration since 1988. Mandalay is only 185 miles away from the Yunnan Province [6, P. 207].

Since SLORC came into power, the progress of Sino-Myanmar relations has begun a remarkable success in the foreign policy of isolate government. However, according to some Myanmar scholars, the military always concerns on Beijing's shadow in their daily routine as the reflection from the historical events of two countries relations. SLORC, yet, they promoted the strategic ties with Beijing, but it does not mean that they wanted to rely on China. As placed in isolation, military leaders need security guarantor for them in the international community. If we continue the investigation in later 1999, researchers could prove the movements of Myanmar's foreign policy in the regional stage. However, Burmese Sinophobia is born due to the military dictators' reliance on China until present time.

\section{REFERENCES}

[1] Lutz-Auras L. Russia and Myanmar - Friends in Need? Journal of Current Southeast Asian Affairs, Vol. 34, No. 2, 2015. P. 165-198, Access mode: https://www.researchgate.net/publication/301545511_Russia_and_Myanmar_-_Friends_ in_Need (accessed: 17.04.2019).

[2] Deutz A. M. United States Human Rights Policy towards Burma: 1988-91, Contemporary Southeast Asia, ISEAS - Yusof Ishak Institute, Vol. 13, No. 2, September 1991, P. 164187, Access mode: https://www.researchgate.net/publication/249915250_United_States_ Human_Rights_Policy_towards_Burma_1988-91 (accessed: 17.04.2019).

[3] Crossette B. Exhausted Burma Struggles in Isolation, The New York Times, March 23, 1987. Access mode: https://www.nytimes.com/1987/03/23/world/exhaustedburma-struggles-in-isolation.html (accessed: 16.04.2019).

[4] BoBo. Bakaba Gaungsaung Thakhin ThanHtun yè nauksone naèyet Myar. (The Last days of the Bakaba leader Thakhin Thanhtun). Access mode: https://www.bbc.com/ burmese/in-depth-45589293 (accessed: 17.04.2019).

[5] Ajay Kamalakaran. How Russia Supported Burma's independence struggle, History, April 05, 2016, Russia Beyond the Headlines, Access mode: https://www.rbth.com/ arts/history/2016/04/05/how-russia-supported-burmas-independence-struggle_581631 (17.4.2019) (accessed: 17.04.2019).

[6] Tin Maung Maung Than. Myanmar And China: A Special Relationship? ISEASYusof Isak Institute, Southeast Asian Affairs, 2003, Access mode: http://www.jstor.org/stable/27913234 (accessed: 02.02.2019).

[7] Kudo Toshihiro, Myanmar's Economic Relations with China: Can China Support the Myanmar Economy? IDE Discussion Paper, Institute of Developing Economics, Japan External Trade Organization (IDE-JETRO), 2006-07-01. Access mode: http://hdl.handle.net/2344/152 (accessed: 20.04.2019).

[8] Burma-China Chronology to 1999, Chronology complied by Burma Peace Foundation, September 1999. Access mode: http://www.ibiblio.org/obl/docs4/ChinaBurma_Chronology.pdf (accessed: 23.04.2019). 
[9] Interview with the Myanmar scholar U Min Tayza via telephone (accessed: 21.04.2019).

[10] Maung Aung Myoe. In The Name of Pauk-Phaw: Myanmar's China Policy Since 1948, Institute of Southeast Asian Studies, Singapore, 2011. P. 107.

[11] U Myo Thit. A Nee Khit Tayout-Myanmar Setsann Yay (Contemporary ChinaMyanmar Relations) (1988-2015). Access mode: https://www.bbc.com/burmese/indepth-41670417 (accessed: 23.04.2019).

[12] Le Bail H., Tournier A., Form Kunming to Mandalay: The New "Burma Road", Developments along the Sino-Myanmar Border since 1988, L'Institut Francais des relations internationals, March 2010. Access mode: http://www.burmalibrary.org/docs08/ IFRI_av25lebailtourniere(en).pdf (accessed: 23.04.2019).

[13] McCarthy S. Ten Years of Chaos in Burma: Foreign Investment and Economic Liberalization under the SLORC-SPDC (1988 to 1998). Pacific Affairs, Summer 2000, P. 233-262, Access mode: https://www.researchgate.net/publication/261742544_Ten_ Years_of_Chaos_in_Burma_Foreign_Investment_and_Economic_Liberalization_und er_the_SLORC-SPDC_1988_to_1998. (accessed: 25.04.2019).

[14] Steinberg D. I. \& Hongwei Fun. Modern China-Myanmar Relations: Dilemmas of Mutual Dependence, NIAS-Nodic Institute of Asian Studies, 2012.

[15] Dingxin Zhao. Decline of Political Control in Chinese Universities and the Rise of the 1989 Chinese Student Movement, Sociological Perspectives, SAGE Publications, Inc., Vol. 40, No. 2, 1997. P. 159-182, Access mode: https://journals.sagepub.com/ doi/abs/10.2307/1389520. (accessed: 25.04.2019).

[16] Kudo Toshihiro. Myanmar's Economic Relations with China: Who benefits and who pay? ANU Press, 2008. Access mode: https://www.jstor.org/stable/j.ctt24hf5k.10 (accessed: 25.04.2019).

Научная статья

\title{
Экспансия китайского бизнеса в Мьянме и китайско-мьянманские отношения (1988-1990)
}

\author{
Волосюк О.В., Вей Ян Пьё Найнг \\ Национальный исследовательский университет \\ «Высшая школа экономики» \\ 109028, Москва, Россия, Покровский бульвар, 11
}

В статье рассматривается эволюция китайско-мьянманских отношений в конце 1980-х годов в результате экономической экспансии Китая. «Восстание 8888» в августе 1988 года было подавлено военными, которые вернули себе власть в Бирме. Осуждая репрессии военного правительства, западные страны и Япония резко сократили помощь стране. Индия закрыла границы и создала лагеря беженцев вдоль границы с Бирмой. Эта ситуация привела к практически полной изоляции Бирмы в международном сообществе. Китай остался ее единственным стратегическим союзником в регионе. Согласно официальной статистике в 1988-1990 годах китайский бизнес в Мьянме был значительно расширен. Однако, несмотря на значительное улучшение торгового диалога, появились такие проблемы, как мигранты и несбалансированная торговля, что создало некоторые «трещины» в китайско-мьянманских отношениях. В статье рассматриваются 
различные случаи, которые вызвали негативное отношение народа Мьянмы к китайцам и даже привели к появлению такого термина, как «синофобия».

Ключевые слова: Бирманская социалистическая программа, Мьянма, Китай, США, CCCP, EC, У Не Вин, незаконная приграничная торговля, SLORC, китайский бизнес, Юньнань, двусторонняя торговля, стратегическое партнерство

\section{Информация об авторах / Information about the authors}

Волосюк Ольга Виленовна - доктор исторических наук, профессор департамента зарубежного регионоведения факультета мировой экономики и мировой политики Национального Исследовательского Университета «Высшая школа экономики». E-mail: ovolosiuk@hse.ru

Olga Volosyuk - Doctor of Sciences in World History, School of International Regional Studies, Faculty of World Economy and International Affairs, National Research University "Higher School of Economics". E-mail: ovolosiuk@hse.ru

Вей Ян Пьё Найнг - аспирант Школы исторических наук, факультета мировой экономики и мировой политики Национального Исследовательского Университета «Высшая школа экономики». E-mail: ywai@ hse.ru

Wai Yan Phyo Naing - Post-Graduate at Doctoral School of History, Faculty of World Economy and International Affairs, National Research University "Higher School of Economics”. E-mail: ywai@ hse.ru

\section{Для цитирования / For citation}

Волосюк О.В., Вей Ян Пьё Найнг. Экспансия китайского бизнеса в Мьянме и китайско-мьянманские отношения (1988-1990) // Вестник Российского университета дружбы народов. Серия: Всеобщая история. 2019. Т. 11. № 4. С. 305-314. http://dx.doi.org/ 10.22363/2312- 8127-2019-11-4-305-314

Volosyuk O., Wai Yan Phyo Naing. Expansion of Chinese Business in Myanmar and Sino-Myanmar Relations (1988-1990) // RUDN Journal of World History. 2019. Vol. 11. No. 4. P. 305-314. http://dx.doi.org/10.22363/2312-8127-2019-11-4-305-314

Рукопись поступила в редакцию / Article received: 04.12.2019 